\title{
Thin Layer Drying Kinetics of Wheat Grain in a Convective Hot-Air Dryer Matouk, A. M. ${ }^{1}$; A. N. El-Sayed ${ }^{2}$; A. Tharwat ${ }^{1}$ and M. A. Farhan ${ }^{1}$ \\ ${ }^{1}$ Agric Eng. Dept., Fac. of Agric., Mansoura Univ. \\ ${ }^{2}$ Crop Dept., Fac. of Agric., Mansoura Univ.
}

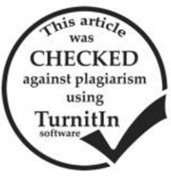

\section{ABSTRACT}

A study was carried out to test and evaluate the drying behavior of wheat grain using a thin layer dryer with controlled air temperature and relative humidity dryer. The studied parameters included four different levels of drying air temperature $(50,55,60$ and $70^{\circ} \mathrm{C}$ ) and four levels of air relative humidity $(30,40,50$ and $60 \%$ ). All the experimental runs were conducted at constant air velocity of $(0.23 \mathrm{~m} / \mathrm{sec})$. The drying behavior of wheat grain during the drying process was simulated using three different thin layer drying models (Lewis's1921 Henderson and Pabis's 1961 and Page 1949 equations). Final quality of the dried wheat grain was also determined. The results show that, drying rate of wheat grain increased with the increase of drying air temperature while, it was decreased with the increase of relative humidity. All studied models could describe the drying behavior of wheat grain. However page model considered the most proper for describing the drying behavior of wheat grain in terms of higher values of $\left(\mathrm{R}^{2}\right)$ and lowest values of (SE).

\section{INTRODUCTION}

Wheat may be considered as one of the most important grain crops in Egypt. Its cultivated area was about 3.351 million fed. In 2016 and the production was 9.342 million tons. In 2017 the planted area of wheat was only 3.194 million fed. And the production was 8.8 million tons (FAO, 2019).

Wheat is usually harvested at relatively high moisture content. Some treatments after harvesting could apply before they may be safely stored. In spite of recent development in chemical treatment, the most usual treatment is drying to safe moisture content.

Drying is essentially a heat and moisture transfer process. That is, heat is moved from the air stream to the material being dried, while moisture moves from the interior of the material and then vaporizes into the air stream, thereby reducing the temperature of the air.

Drying rate can be increased in general either by using a higher air temperature or reducing air relative humidity. In most of drying studies conducted by previous researchers, hot air was used to remove the moisture from grains. To retain wheat grains quality, it is necessary to be able to predict the changes in its moisture content which will occur in such storage, because of high initial moisture contents at which harvest was conducted. This prediction may be made by using the basic thermal and water relations of the wheat grains (var. Gemiza 11). These relations require knowledge of the rate of moisture movement out of the wheat grains.

The general objectives of this work were attempting the provided rational basis for drying systems, in which forced heated air at constant temperature and relative humidity may be used.

The specific objectives of this study were:

1- Developing and selecting the most proper mathematical model which may describe the loss of moisture during thin layer drying of wheat grains.

2- Studying and describing mathematically the effect of both air temperatures and air relative humidity on the drying rate of wheat grains.
3- Determining the drying coefficients in the developed models to the experimental variables.

Generally, it is hoped that this study will provide a basis for further studies leading to better understanding and complete solution of wheat grains deep bed drying and in turn better understanding of the criteria of safe storage of wheat grains.

\section{MATERIALS AND METHODS}

Freshly harvested of wheat variety were used in this study. It was obtained from the harvested wheat grains (Gemiza 11) from the farm of faculty of Agricultural College - Mansoura University. It had initial moisture content range less than (14\%, w.b.). Conducted moisturizing grain process between (24-26)

$\%$. The wheat grain were put in plastic sacks sealed and saved into refrigerated panel at $5{ }^{\circ} \mathrm{C}$ in conformity with prevent fungal growth. Before each experimental run, the wheat crop was took out of the refrigeration and left under ambient conditions to reach room temperature.

To accomplish the target of the present investigation, a controlled drying air temperature and relative mugginess lab scale dryer created and introduced at the Agricultural Engineering Department, Faculty of Agric. Mansoura University was utilized. The dryer could produce any coveted state of the drying air temperature, relative mugginess and speed. The principle parts of the dryer included $1.3 \mathrm{~kW}$ outward blowers with straight impeller, dampness control framework in which water was spread and coursed through a humidification tower with the end goal to give and keep up the drying air at the coveted dew point temperature by methods for an indoor regulator with a precision of $\pm 0.1^{\circ} \mathrm{C}$. The air temperature was controlled utilizing air warming unit with a temperature controller for exact modification of the drying air temperature. The examples were suited in drying chamber comprised of excited steel barrel $(27 \mathrm{~cm}$ distance across and $70 \mathrm{~cm}$ long) and a drying plate set inside the chamber as appeared in Fig.(1). 


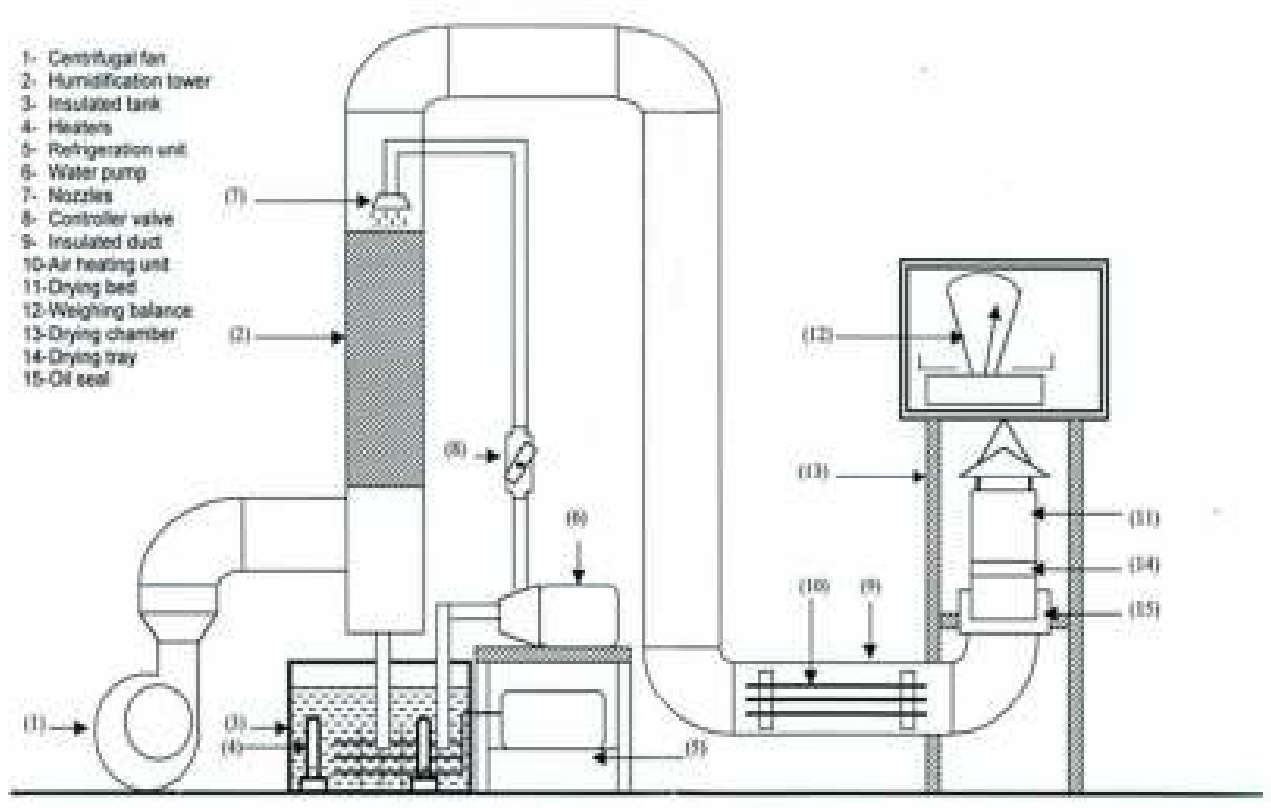

Fig. 1. Diagrammatic section of the laboratory scale dryer.

Experimental Measurements and Measuring Equipment. 1. Air temperature and relative humidity :

A temperature and relative humidity meter model (Trotec - 2000S) connected to an Iron-Constantine thermocouple type (T) was used to measure both parameters .

\section{Air velocity:}

A TRI-SENSE temperature/ humidity/ air velocity meter (model Trotec 2000S) was used for measuring air velocity over the samples surface with an accuracy of $0.01 \mathrm{~m} / \mathrm{s}$.

\section{Mass measurement :}

The mass of samples was recorded using a digital balance with accuracy of $0.01 \mathrm{~g}$.

\section{Moisture content of wheat grain :}

In this examination, the wheat dampness content was controlled by drying $10 \mathrm{~g}$ test in a convection air broiler at $130^{\circ} \mathrm{C}$ for $19 \mathrm{~h}$ as per ASAE standard D352.2 (Kassem, 1998). The estimation of wheat grain dampness content was completed with five replicates. It ought to be said here that all dampness substance were communicated in dry premise except if generally indicated.

Experimental procedure:

Wheat was cleaned by expelling undesired stems and debasements, separated manually under careful observation and the sound wheat was utilized for the test work. Before each test run, air temperature relative dampness and speed had been balanced out, the wheat grain were consistently spread in thin layers of $400 \mathrm{~g}$ for each sample in the punctured drying plate and raced into the dryer bed. In the meantime three sub tests each one of $10 \mathrm{~g}$ were taken from the fresh wheat grain and kept in an aluminum tin to decide the underlying dampness content, the weight changes of the samples were recorded amid the drying procedure like clockwork amid the first hours and at regular intervals up to the finish of each run, or until the point that the dampness substance of wheat grain had moved toward the harmony condition with the drying air. Toward the finish of each drying run the last weight of wheat grain were surveyed and afterward the dried grain were utilized to decide the final dampness content as clarified before. In order to minimize the test errors of each run, it was repeated multiple times, and the average reading was considered.

\section{Simulation of the Drying Dat:}

The obtained data of the laboratory experiments were employed to examine the applicability of the three studied thin layer drying models (Lewis's 1921, Henderson and Pabis's 1961 and Page 1949 equations) on describing and simulating the drying data. The examined drying models could be presented as follows:

\section{1- Lewis's model}

$$
M R=\frac{M-M_{f}}{M_{o}-M_{f}}=\exp (-k t)
$$

Where:

MR: moisture ratio, dimensionless.

$k$ : the drying coefficient.

M: moisture content at time $t$

Mo: initial moisture content

Mf: final moisture content

t: drying time

The values of the drying constant $\left(\mathrm{k}_{\mathrm{L}}\right)$ for the Lewis's model (1) could be obtained from the relationship between the natural logarithm Ln (MR) of the tested sample versus the drying time $(\mathrm{t})$ as follows:

$$
\text { Ln MR }=-\mathbf{k}_{\mathbf{L}} \mathbf{t}
$$

The drying constant $\left(\mathrm{k}_{\mathrm{L}}\right)$ represented by the slope of the equation.

Henderson and Pabis's model :

$$
M R=A_{H} \exp \left(-K_{H} t\right)
$$

\section{Where:}

$\mathbf{k}_{\mathrm{H}}$ : Drying constant, $\operatorname{~min}^{-1}$

$A_{H}$ : Drying constant, dimensionless. 
The values of drying constants $\left(\mathrm{k}_{\mathrm{H}}\right)$ and $\left(\mathrm{A}_{\mathrm{H}}\right)$ for Henderson and Pabis's (equation 2) could be also obtained from the relationship between Ln (MR) versus the drying time $(\mathrm{t})$ as follows:

\section{$\operatorname{Ln} M R=\operatorname{Ln} A_{H}-k_{H} t$}

The drying constant $\left(\mathrm{k}_{\mathrm{H}}\right)$ represented by the curve slope while, the constant $\left(\mathrm{A}_{\mathrm{H}}\right)$ represented by the intercept. Page's model:

1- Page's model:

$$
M R=\frac{M_{f}-M_{f}}{M_{o}-M_{f}}=\exp \left(-k t^{u}\right) \cdots \cdot
$$

Where:

$K_{p}$ and $u$ : the drying constants.

The drying constants $\left(\mathrm{k}_{\mathrm{P}}\right)$ and $(\mathrm{u})$ of Page's model were determined after plotting the values of $\operatorname{Ln}(-\operatorname{Ln}(\mathrm{MR}))$ versus the drying time $(\operatorname{Ln}(\mathrm{t}))$ as follows:

$$
(\operatorname{Ln}(-\operatorname{Ln}(M R)))=\operatorname{Ln}\left(k_{\mathbf{P}}\right)+\mathbf{u} \operatorname{Ln}(t)
$$

The slope of the drying curve represents the drying constant $(\mathrm{kP})$ while the constant $(\mathrm{u})$ represents the y-intercept.

Statistical analysis:

Relapse investigations were finished by utilizing the Statistical schedule. The coefficient of relationship (r) was one of the essential standards for choosing the best condition to characterize the thin layer drying bends of wheat grain (Zogzas et al., 1994, 1996; Ketelaars et al., 1995; Singh; et al., 2007). Notwithstanding r, the different factual parameters, for example, decreased chi-square $\left(\chi^{2}\right)$, mean bias error (MBE) and root mean square error (RMSE) were utilized to decide the nature of the fit. These parameters can be computed as following:

$$
\begin{aligned}
& \chi^{2}=\frac{\sum_{i=1}^{N}\left(\begin{array}{lll}
\text { obs } ., i & -M R_{\text {calc }}, i
\end{array}\right)^{2}}{N-n} \\
& R M S E=\left[\frac{1}{N} \sum_{i=1}^{N}\left(M R_{\text {calc }, i}-M R_{o b s, i}\right)^{2}\right]^{1 / 2} \ldots
\end{aligned}
$$

Where $\mathbf{M R}_{\text {obsi }}$ remains for the watched dampness proportion found in any estimation and $\mathbf{M R}_{\text {calci } i}$ is the computed dampness proportion for this estimation. $\mathrm{N}$, the quantity of perceptions, (Pangavhane, Sawhney, and , Sarsavadia, 1999).

\section{RESULTS AND DISCUSSION}

\section{Effect of Air Relative Humidity and Air Temperature on the Drying Rate:}

Figures (4-1 and 4-2) show the representative drying curves for runs no. $1,4,7,10,13,18,23,28$, and 33. It can be seen that both air temperatures and air relative humidity had a great effect on the behavior of the drying process. As the drying air temperature increases and the relative humidity decreases the drying rate of the wheat grains increase.

\section{Thin Layer Drying Equations:}

Wheat grains samples were dried from initial moisture content ranging from $33.17 \%$ to $34.81 \%$ (d.b.) to a final moisture content ranging from $7.41 \%$ to $9.974 \%$ (d.b.) with air temperature ranging from 50 to $70{ }^{\circ} \mathrm{C}$ and relative humidity in rang of $30 \%-60 \%$. The results show that all the drying process occurred at the falling rate period in which the rate of evaporation tends to fall as the moisture content decreases and the drying curve decays exponentially towards final moisture values.

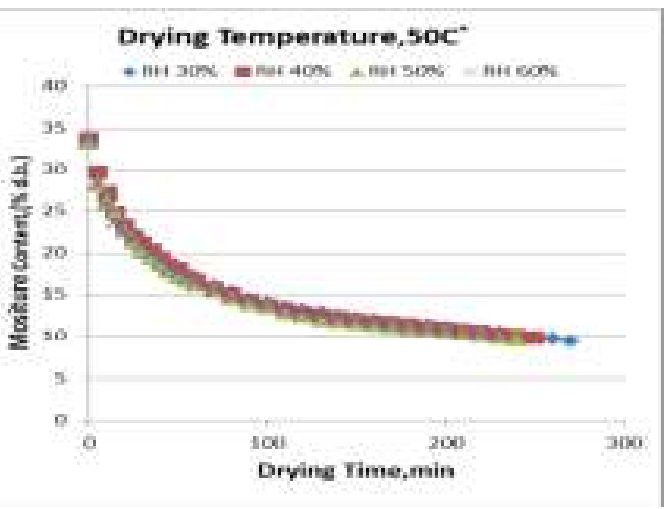

Figure 2. Effect of the air relative humidity at constant air temperature on the drying process

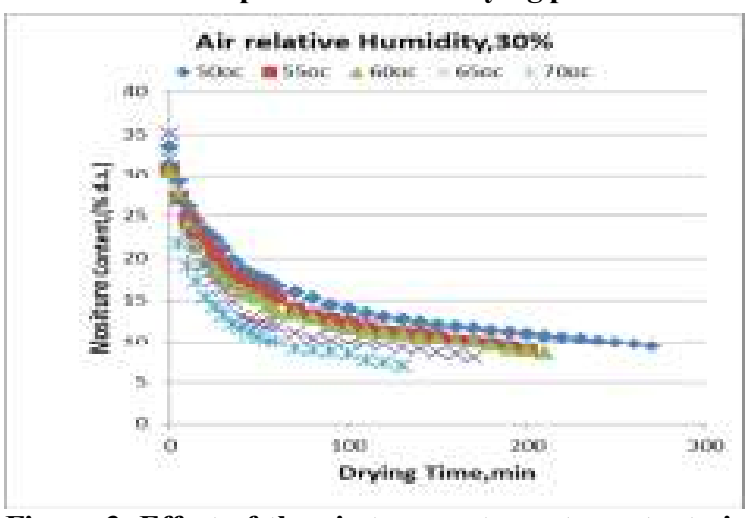

Figure 3. Effect of the air temperature at constant air relative humidity on the drying process

These analysis based on using the final moisture content $\left(\mathbf{M}_{\mathrm{f}}\right)$.

1. Thin layer drying based on Lewis' model:

The obtained experimental data was analyzed using the exponential equation (1) In form that, the equilibrium moisture content was considered as the final moisture content and the moisture ratio could be expressed as $M R=\left(M-M_{f}\right) /\left(M_{0}-M_{f}\right)$. Figure (4) shows representative curve showing the relationship between $\left(\mathrm{K}_{\mathrm{L}}\right)$ and $(\mathrm{Ta})$ at different levels of air relative humidity.

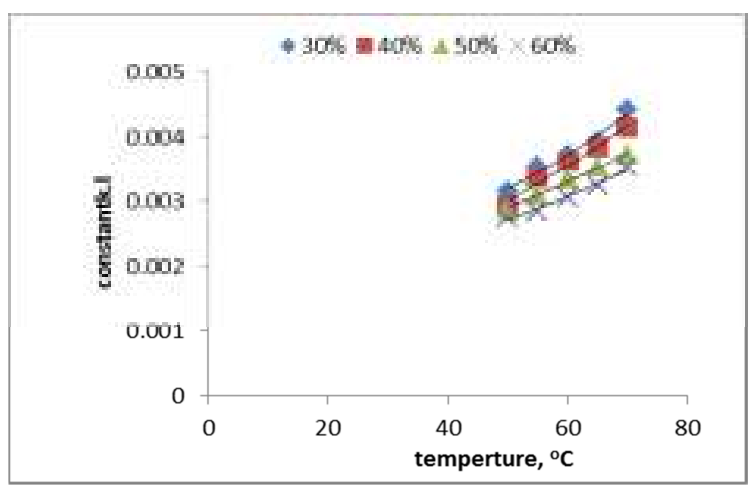

Figure 4. Relation between $\left(K_{L}\right)$ and $T_{a}$ deferent levels of relative humidity. 
As shown in Table (1), the drying constant $\left(\mathrm{k}_{\mathrm{L}}\right)$ increased with the increase of drying air temperature, while it was decreased with the increase of drying air relative humidity. A multiple regression analysis was proceeded to relate the drying air temperature (Ta) and the relative humidity $(\mathrm{RH})$ with the drying constant $\left(\mathrm{k}_{\mathrm{L}}\right)$ at constant air velocity of $0.23 \mathrm{~m} / \mathrm{sec}$.

Table 1. Values of drying coefficient $\left(K_{L}\right)$.

\begin{tabular}{lccccc}
\hline $\mathbf{T}_{\mathbf{a}}$ & $\mathbf{R H}$ & $\mathbf{K}_{\mathbf{L}}$ & $\mathbf{T}_{\mathbf{a}}$ & $\mathbf{R H}$ & $\mathbf{K}_{\mathbf{L}}$ \\
\hline \multirow{6}{*}{50} & $30 \%$ & 0.00314 & & $30 \%$ & 0.00393 \\
& $40 \%$ & 0.00293 & 65 & $40 \%$ & 0.00384 \\
& $50 \%$ & 0.00287 & & $50 \%$ & 0.00352 \\
& $60 \%$ & 0.00275 & & $60 \%$ & 0.00324 \\
\hline \multirow{5}{*}{55} & $30 \%$ & 0.00354 & & $30 \%$ & 0.00441 \\
& $40 \%$ & 0.00336 & 70 & $40 \%$ & 0.00414 \\
& $50 \%$ & 0.0031 & & $50 \%$ & 0.00372 \\
& $60 \%$ & 0.00284 & & $60 \%$ & 0.00353 \\
\hline \multirow{6}{*}{60} & $30 \%$ & 0.00372 & & \\
& $40 \%$ & 0.00361 & & & \\
& $50 \%$ & 0.00335 & & & \\
\hline
\end{tabular}

To determine the interaction effect of both drying air temperature and air relative humidity on the drying coefficient $\left(\mathrm{K}_{\mathrm{L}}\right)$. A multiple regression analysis was employed and the following equation was obtained:

$\left(K_{L}=0.001474+0.0000496\right.$ Ta -0.000023 RH.

$$
\text { (S.E. } \left.=0.0000901-R^{2}=0.964\right)
$$

Thin layer drying based on Henderson and Pabis' model Figures (5) and (6) show representative curves of the relationship between (A) and both air temperature and air relative humidity.

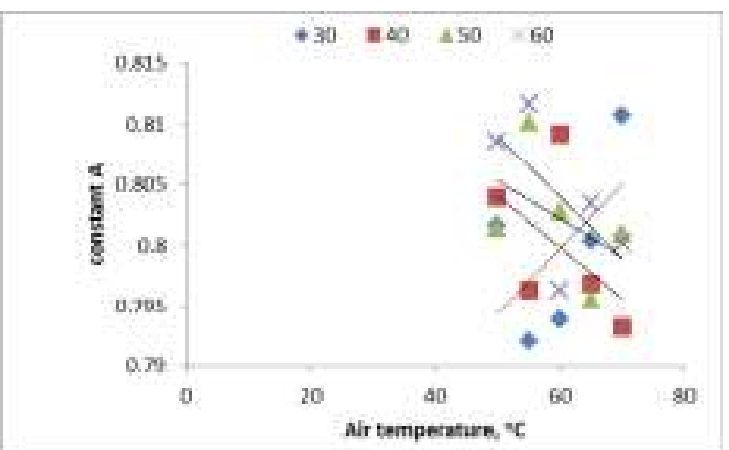

Figure 5. Relationship between $\left(A_{H}\right)$ and $T_{a}$ at different levels of relative humidity.

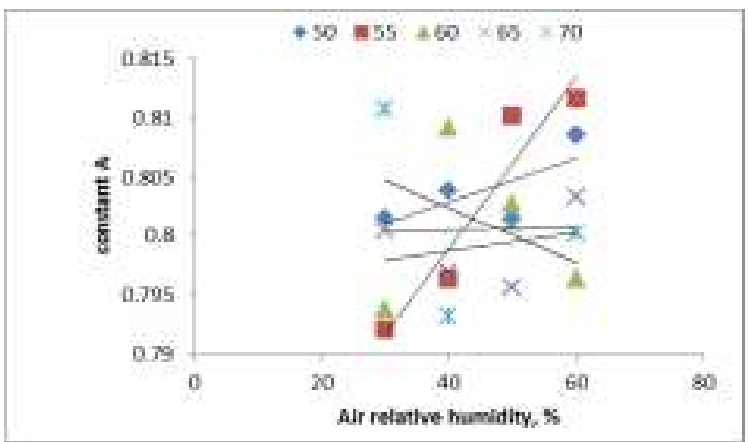

Figure 6. Relation between (A) and RH at different levels of air temperature

The values of drying coefficients $\left(A\right.$ and $\left.K_{H}\right)$ could be obtained from the relationship between the time and the moisture content at constant time intervals based on equation (2). The calculated values of drying coefficients $\left(A\right.$ and $K_{H}$ ) are given in table (2). From table (2), it can be seen that the drying coefficient (A) values were varying with both air temperature and air relative humidity. Otherwise, the computed values of the drying coefficient (A) showed low dependence on both air temperatures and air relative humidity and ranged from $(0.79206$ to $0.811622)$ with average of (0.801449). Meanwhile, the drying coefficient $\left(\mathrm{K}_{\mathrm{H}}\right)$ values showed dependence on both air temperature and air relative humidity.

Table 2. Values of drying coefficients $\left(A_{H}\right.$ and $\left.K_{H}\right)$.

\begin{tabular}{lccccccc}
\hline $\mathbf{T}_{\mathbf{a}}$ & $\mathbf{R H}$ & $\mathbf{A}_{\mathbf{H}}$ & $\mathbf{K}_{\mathbf{H}}$ & $\mathbf{T}_{\mathbf{a}}$ & $\mathbf{R H}$ & $\mathbf{A}_{\mathbf{H}}$ & $\mathbf{K}_{\mathbf{H}}$ \\
\hline & $30 \%$ & 0.801577 & 0.01532 & & $30 \%$ & 0.800369 & 0.01814 \\
50 & $40 \%$ & 0.8039 & 0.014312 & 65 & $40 \%$ & 0.796887 & 0.01702 \\
& $50 \%$ & 0.801434 & 0.014169 & $50 \%$ & 0.7956 & 0.016942 \\
& $60 \%$ & 0.808546 & 0.013827 & $60 \%$ & 0.803395 & 0.016324 \\
\hline & $30 \%$ & 0.792062 & 0.01553 & $30 \%$ & 0.810709 & 0.022246 \\
55 & $40 \%$ & 0.796299 & 0.015012 & 70 & $40 \%$ & 0.793166 & 0.021884 \\
& $50 \%$ & 0.810184 & 0.014952 & $50 \%$ & 0.800938 & 0.021845 \\
& $60 \%$ & 0.811622 & 0.013967 & $60 \%$ & 0.80017 & 0.021028 \\
\hline \multirow{2}{*}{60} & $30 \%$ & 0.793797 & 0.01753 & & & \\
& $40 \%$ & 0.809184 & 0.01725 & & & \\
& $50 \%$ & 0.802789 & 0.017025 & & & \\
& $60 \%$ & 0.796344 & 0.01581 & & & \\
\hline
\end{tabular}

Thin layer drying based on Page's model:

Based on equation (3), which mentioned before, the mathematical analysis of the drying coefficients $\left(\mathrm{K}_{\mathrm{P}}\right.$ and $\left.\mathrm{u}\right)$ was proceeded to obtain the nature of the relationship between drying coefficients and the parameters of drying equations.

Figures (7) through (10) show representative curves of the relationship between $\left(K_{P}\right.$ and $\left.u\right)$ and both air temperature and air relative humidity.

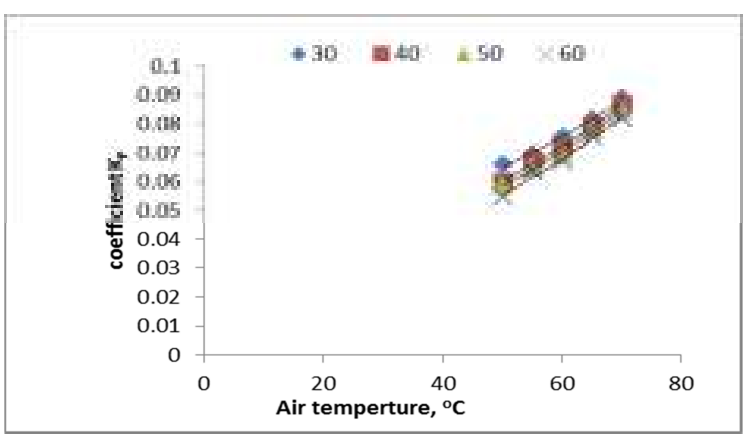

Figure 7. Relationship between $\left(K_{P}\right)$ and $T_{a}$ at different levels of relative humidity.

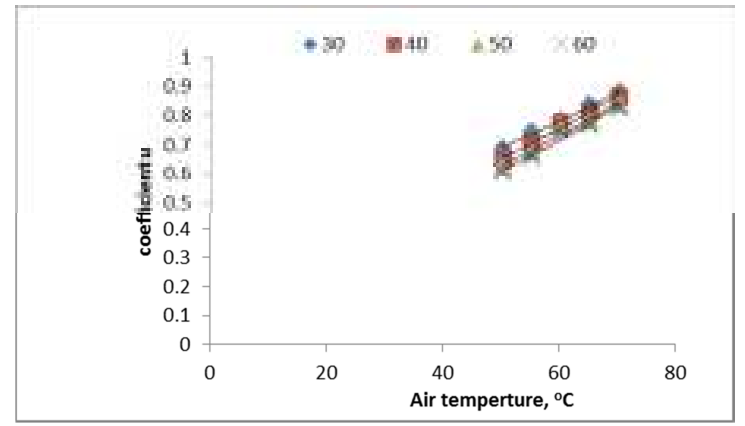

Figure 8. Relation between (u) and $T_{a}$ at different levels of relative humidity. 


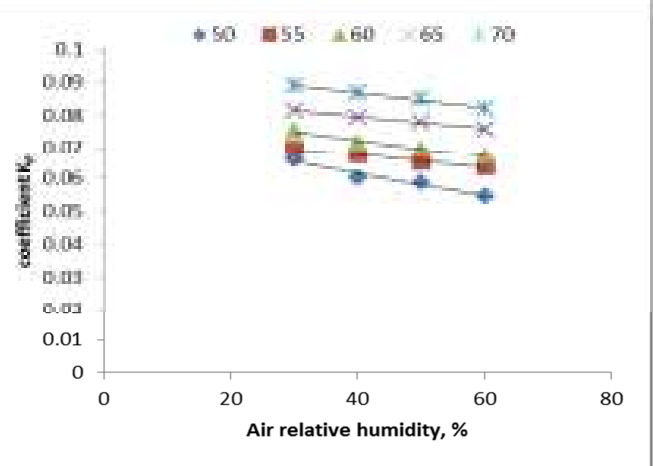

Figure 9. Relation between $\left(K_{P}\right)$ and $R H$ at different levels of air temperature.

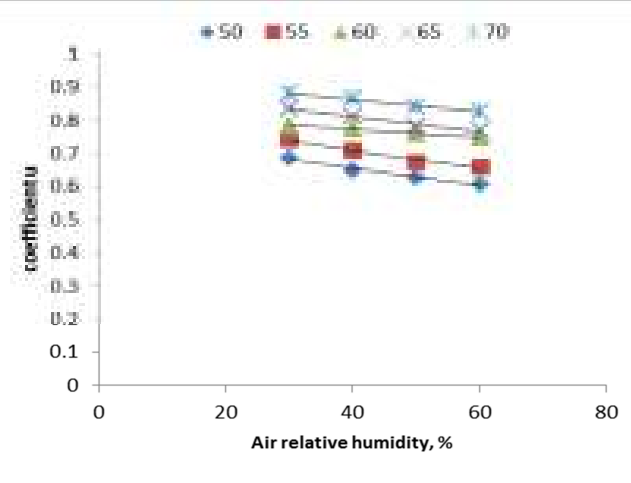

Figure 10. Relation between (u) and RH at different levels of air temperature.

As shown in Table (3), both drying constants $\left(\mathrm{k}_{\mathrm{P}}\right)$ and $(\mathrm{u})$ increased with the increase of drying air temperature, while the drying constant $\left(\mathrm{k}_{\mathrm{P}}\right)$ decreased with the increase of drying air relative humidity and drying constants (u) increased with the increase of air relative humidity.

Table 3. Values of drying coefficients $\left(K_{P}\right.$ and $\left.u\right)$.

\begin{tabular}{cccccccc}
\hline $\mathbf{T}_{\mathbf{a}}$ & $\mathbf{R H}$ & $\mathbf{K}_{\mathbf{P}}$ & $\mathbf{u}$ & $\mathbf{T}_{\mathbf{a}}$ & $\mathbf{R H}$ & $\mathbf{K}_{\mathbf{P}}$ & $\mathbf{u}$ \\
\hline \multirow{5}{*}{50} & $30 \%$ & 0.065965 & 0.6862 & & $30 \%$ & 0.08154 & 0.8364 \\
& $40 \%$ & 0.06024 & 0.6481 & $65 \%$ & $40 \%$ & 0.07927 & 0.8114 \\
& $50 \%$ & 0.05872 & 0.6254 & $50 \%$ & 0.07784 & 0.7825 \\
& $60 \%$ & 0.054624 & 0.6045 & $60 \%$ & 0.07581 & 0.7694 \\
\hline \multirow{4}{*}{55} & $30 \%$ & 0.06954 & 0.7421 & $30 \%$ & 0.08894 & 0.8806 \\
& $40 \%$ & 0.06741 & 0.7085 & 70 & $40 \%$ & 0.08673 & 0.8647 \\
& $50 \%$ & 0.06502 & 0.6745 & $50 \%$ & 0.08491 & 0.8406 \\
& $60 \%$ & 0.063621 & 0.6582 & $60 \%$ & 0.08201 & 0.8268 \\
\hline \multirow{6}{*}{60} & $30 \%$ & 0.075287 & 0.7851 & & & \\
& $40 \%$ & 0.07168 & 0.7743 & & & \\
& $50 \%$ & 0.06947 & 0.7602 & & & \\
& $60 \%$ & 0.06726 & 0.7487 & & & \\
\hline
\end{tabular}

To determine the interaction effect of drying air temperature and air relative humidity on the drying coefficients $\left(\mathrm{K}_{\mathrm{P}}\right.$ and $\left.\mathrm{u}\right)$, a multiple regression analysis was employed and the following equations were obtained:

$$
\begin{array}{r}
(K P=0.006898+0.001275 T-0.00025 ~ R H . . \\
\left(S E=0.001178, \quad R^{2}=0.9869\right) \\
(u=0.215688+0.010567 T-0.00218 R H . . .
\end{array}
$$$$
\left(\mathrm{SE}=0.011748, \quad \mathrm{R}^{2}=0.98137\right)
$$

Comparative evaluation of the studied drying models

A general comparison between the examined models (1), (2) and (3) to assess the most proper model for describing the drying behavior of wheat grains was made.
The results show that the Page's model was the best equation in describing the drying behavior of wheat grains, followed by the Lewis' model and Henderson and Pabis' model.
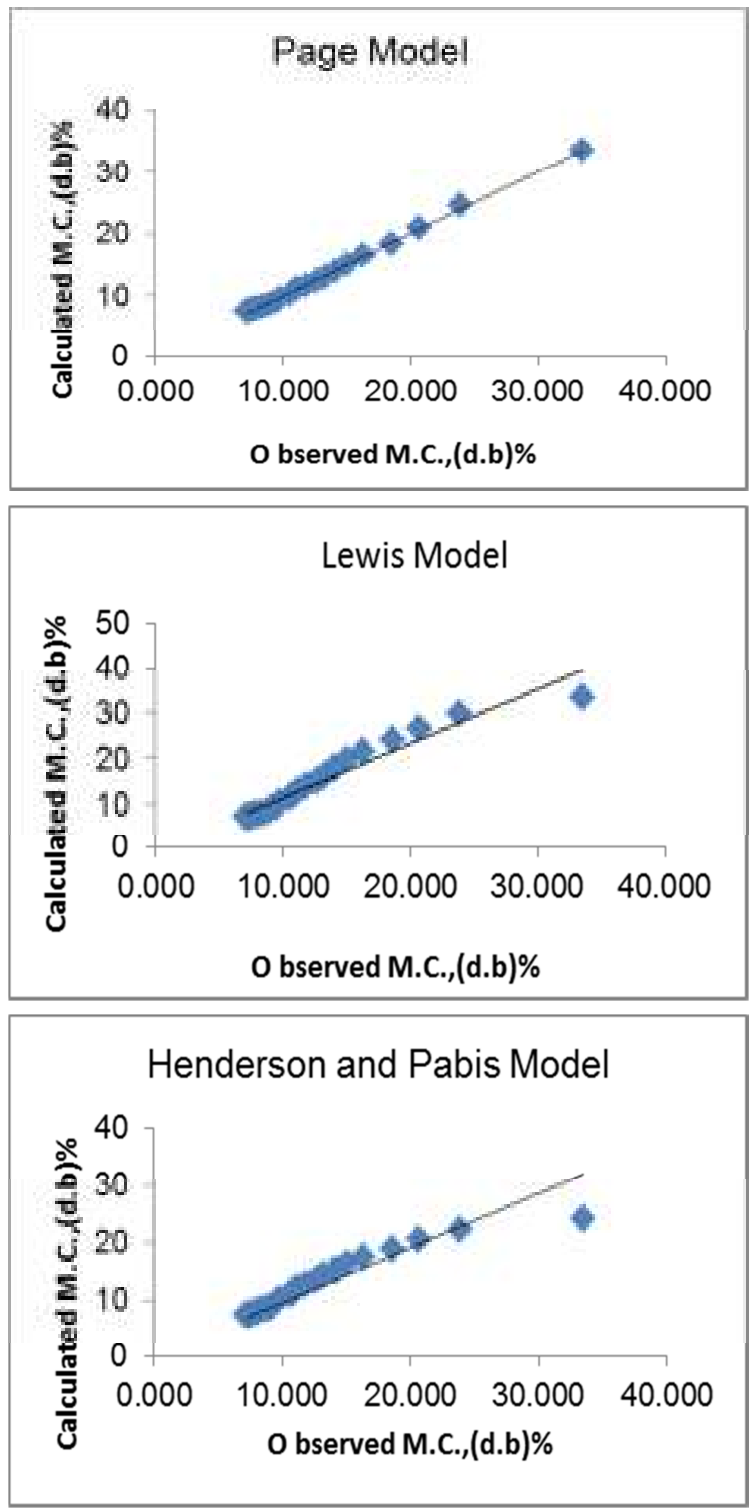

Figure 11. A comparison between the observed and calculated moisture content which calculated from the tested models at temperature of $70^{\circ} \mathrm{C}$ and relative humidity $30 \%$

\section{Quality of wheat grain}

Table (4) also shows the observed and calculated values of moisture ratio as calculated by different models at temperature of $70^{\circ} \mathrm{C}$ and deferent levels of air relative humidity.

The same pattered was also found for all experimental runs. In other words we may say that the Page's model could be considered the most suitable equation in describing the drying behavior of wheat grains during thin layer drying process. 
Table 4. A comparison between the observed and calculated moisture content obtained from each model at air temperature of $70^{\circ} \mathrm{C}$ and different levels of air relative humidity.

\begin{tabular}{|c|c|c|c|c|c|c|c|c|c|c|c|c|c|c|c|c|}
\hline \multirow{2}{*}{$\begin{array}{l}\text { Drying } \\
\text { Time, } \\
\text { (min) }\end{array}$} & \multirow[b]{2}{*}{$\begin{array}{l}{ }^{*} \mathrm{MC}_{0} \\
\%(\mathbf{d b})\end{array}$} & \multicolumn{3}{|c|}{$* \mathrm{MC}_{\mathrm{o}} \%(\mathrm{db})$ atRH,30\% } & \multirow[b]{2}{*}{$\begin{array}{r}\mathrm{MC}_{\mathbf{0}} \% \\
\text { (db) }\end{array}$} & \multicolumn{3}{|c|}{$\mathrm{MC}_{0} \%(\mathrm{db})$ at RH, $40 \%$} & \multirow{2}{*}{$\begin{array}{c}\mathrm{MC}_{\mathrm{o}} \% \\
\text { (d.) }\end{array}$} & \multicolumn{3}{|c|}{$\mathrm{MC}_{0} \%(\mathrm{db})$ at RH,50\% } & \multirow{2}{*}{$\begin{array}{l}\mathrm{MC}_{\mathrm{d}} \% \\
\text { (db) }\end{array}$} & \multicolumn{3}{|c|}{ MC. $\%(d b)$ at RH, $60 \%$} \\
\hline & & $\begin{array}{l}\text { Lewis' } \\
\text { modd }\end{array}$ & $\begin{array}{c}\text { H.andP. } \\
\text { model }\end{array}$ & $\begin{array}{l}\text { Pagels } \\
\text { model }\end{array}$ & & $\begin{array}{l}\text { Lewis' } \\
\text { model }\end{array}$ & $\begin{array}{c}\text { H.andP. } \\
\text { model }\end{array}$ & $\begin{array}{l}\text { Pagels } \\
\text { model }\end{array}$ & & $\begin{array}{l}\text { Lewis' } \\
\text { modd }\end{array}$ & $\begin{array}{l}\text { H.andP. } \\
\text { model }\end{array}$ & $\begin{array}{l}\text { Pagels } \\
\text { model }\end{array}$ & & $\begin{array}{l}\text { Lewis' } \\
\text { model }\end{array}$ & $\begin{array}{c}\text { H.andP. } \\
\text { moddl }\end{array}$ & $\begin{array}{l}\text { Pagels } \\
\text { moddl }\end{array}$ \\
\hline 0 & 33.5 & 33.5 & 24.3 & 33.5 & 32.4 & 32.4 & 27.0 & 32.4 & 34.9 & 34.9 & 25.8 & 34.9 & 38.0 & 38.0 & 28.7 & 38.0 \\
\hline 5 & 24.6 & 29.8 & 22.2 & 23.9 & 24.6 & 28.3 & 23.9 & 23.1 & 26.7 & 30.7 & 23.4 & 27.0 & 27.6 & 32.7 & 25.3 & 26.8 \\
\hline 10 & 20.9 & 26.7 & 20.5 & 20.7 & 20.8 & 24.9 & 21.3 & 20.4 & 22.6 & 27.1 & 21.3 & 23.0 & 22.8 & 28.3 & 22.5 & 23.1 \\
\hline 15 & 18.4 & 24.0 & 18.9 & 18.6 & 18.1 & 22.0 & 19.1 & 18.4 & 19.8 & 24.1 & 19.4 & 19.9 & 19.6 & 24.6 & 20.1 & 20.6 \\
\hline 20 & 16.6 & 21.6 & 17.5 & 16.3 & 16.1 & 19.5 & 17.2 & 16.8 & 17.6 & 21.5 & 17.8 & 17.8 & 17.3 & 21.6 & 18.1 & 18.5 \\
\hline 25 & 15.2 & 19.6 & 16.3 & 15.0 & 14.6 & 17.5 & 15.7 & 15.3 & 16.0 & 19.3 & 16.5 & 16.2 & 15.5 & 19.1 & 16.4 & 16.8 \\
\hline 30 & 14.0 & 17.9 & 15.2 & 14.1 & 13.3 & 15.8 & 14.3 & 14.2 & 14.6 & 17.5 & 15.2 & 14.8 & 14.1 & 17.1 & 15.0 & 14.8 \\
\hline 35 & 13.1 & 16.4 & 14.3 & 13.3 & 12.3 & 14.3 & 13.2 & 13.2 & 13.5 & 15.9 & 14.2 & 13.6 & 13.0 & 15.4 & 13.8 & 13.9 \\
\hline 40 & 12.3 & 15.1 & 13.4 & 12.7 & 11.5 & 13.1 & 12.2 & 12.2 & 12.6 & 14.6 & 13.3 & 12.6 & 12.1 & 14.0 & 12.7 & 13.5 \\
\hline 45 & 11.7 & 14.0 & 12.7 & 11.8 & 10.9 & 12.1 & 11.4 & 11.4 & 11.9 & 13.5 & 12.5 & 11.7 & 11.3 & 12.8 & 11.9 & 12.4 \\
\hline 50 & 11.2 & 13.0 & 12.0 & 11.2 & 10.3 & 11.2 & 10.7 & 10.8 & 11.3 & 12.5 & 11.8 & 11.0 & 10.7 & 11.8 & 11.2 & 11.9 \\
\hline 55 & 10.7 & 12.2 & 11.5 & 10.9 & 9.8 & 10.5 & 10.1 & 9.7 & 10.7 & 11.7 & 11.2 & 10.5 & 10.2 & 11.0 & 10.5 & 11.2 \\
\hline 60 & 10.3 & 11.5 & 10.9 & 10.6 & 9.4 & 9.9 & 9.6 & 9.2 & 10.3 & 11.0 & 10.7 & 10.1 & 9.8 & 10.4 & 10.0 & 10.2 \\
\hline 70 & 9.7 & 10.4 & 10.1 & 9.8 & 8.8 & 9.0 & 8.8 & 8.9 & 9.6 & 10.0 & 9.8 & 9.7 & 9.2 & 9.4 & 9.2 & 9.8 \\
\hline 80 & 9.2 & 9.5 & 9.4 & 9.5 & 8.3 & 8.4 & 8.2 & 8.6 & 9.0 & 9.2 & 9.2 & 9.4 & 8.7 & 8.7 & 8.6 & 9.5 \\
\hline 90 & 8.8 & 8.9 & 8.9 & 9.1 & 8.0 & 7.9 & 7.8 & 8.2 & 8.6 & 8.6 & 8.7 & 9.0 & 8.3 & 8.2 & 8.2 & 8.9 \\
\hline 100 & 8.5 & 8.4 & 8.5 & 8.8 & 7.7 & 7.6 & 7.5 & 7.9 & 8.3 & 8.2 & 8.4 & 8.5 & 8.1 & 7.9 & 8.0 & 8.5 \\
\hline 110 & 8.3 & 8.1 & 8.2 & 8.3 & 7.5 & 7.3 & 7.3 & 7.5 & 8.1 & 8.0 & 8.1 & 8.3 & 7.9 & 7.7 & 7.7 & 8.2 \\
\hline 120 & 8.1 & 7.8 & 8.0 & 8.1 & 7.4 & 7.2 & 7.2 & 7.3 & 7.9 & 7.8 & 7.9 & 8.1 & 7.7 & 7.6 & 7.6 & 7.8 \\
\hline 130 & 7.9 & 7.7 & 7.8 & 7.8 & 7.2 & 7.1 & 7.1 & 7.0 & 7.8 & 7.6 & 7.7 & 7.9 & 7.6 & 7.5 & 7.5 & 7.5 \\
\hline 140 & 7.8 & 7.5 & 7.6 & 7.7 & 7.2 & 7.0 & 7.0 & 7.0 & 7.7 & 7.5 & 7.6 & 7.8 & 7.6 & 7.4 & 7.4 & 7.2 \\
\hline 150 & 7.7 & 7.4 & 7.5 & 7.5 & 7.1 & 6.9 & 6.9 & 6.8 & 7.6 & 7.4 & 7.5 & 7.2 & -- & -- & -- & -- \\
\hline 160 & 7.6 & 7.3 & 7.4 & 7.3 & --- & --- & -- & --- & --- & --- & --- & --- & --- & --- & --- & --- \\
\hline 170 & 7.5 & 7.3 & 7.4 & 7.1 & --- & --- & --- & --- & --- & --- & --- & --- & --- & --- & --- & --- \\
\hline$x^{2}$ & & 7.984 & 4.542 & 0.075 & & 3.891 & 1.734 & 0.310 & & 4.993 & 4.682 & 0.059 & & 6.787 & 4.813 & 0.686 \\
\hline RMSE & & 0.565 & 0.417 & 0.053 & & 0.411 & 0.274 & 0.116 & & 0.465 & 0.451 & 0.050 & & 0.555 & 0.467 & 0.176 \\
\hline
\end{tabular}

* $\mathrm{MC}_{\mathbf{0}}$ : observed moisture content.

**MC : calculated moisture content.

\section{CONCLUSION}

1- A general comparison between the studied models of Lewis, Henderson and Page showed the applicability of all models in describing the drying behavior of wheat grains under different combinations of drying air temperature and air relative humidity.

2- Page's model could be considered the most proper model for describing the drying behavior of the thin layer drying of wheat grains.

3- The new obtained mathematical relationships for the constant values of each model under the experimental parameters of this study could be useful in predicting and simulating the drying behaviour of a deep bed drying of wheat grains.

\section{REFERENCES}

Lewis, W.K. (1921). The rate of drying of solid materials J. of Ind. Eng. Chem. 13(5): 427-432.

Henderson, S.M.; and S. Pabis, (1961). Grain drying theory. 1. Temperature effect on drying coefficient. J. Agric. Engng. Res., 6(31), 169-174

Page, G.E. (1949). Factor influencing the maximum rates of air mech. Eng., purdue Univ.
FAO (2019). Food and Agriculture Organization. Faostat, FAO Statistics Division, January, 2019.

Zogzas N P; Maroulis Z B; Marinos-Kouris D (1994). Moisture diffusivity: methods of experimental determination. A review. Drying Technology, 12(3), 483-5160).

Zogzas N P; Maroulis Z B; Marinos-Kouris D (1996). Moisture diffusivity data compilation in foodstuds. Drying Techno -logy, 14(10), 2225-2254.

Ketelaars A A J; Pel L; Coumans J; Kerkhof P J A M (1995). Drying kinetics: a comparison of diffusion coefficients from moisture concentration profiles and drying curves. Chemical Engineering Science, 50(7), 1187-1191).

Singh, C.B.; Bal, S.; Ghosh, P.K.; Jayas, D.S.(2007), Thin layer drying model for natural convection drying of parboiled paddy. International Agricultural Engineering Journal 2007, 16(3-4), 179-188.

Pangavhane, D. R.; R. L. Sawhnew; and P. N. Sarsavadia (2000). Drying kinetic studies on single later Thompson seedless grape controlled heated air conditions. Journal of Food Engineering and preservation, 24, 335-352.

Kassem, A. S. (1998). Comparative studies on thin layer drying models for wheat. $13^{\text {th }}$ International Congress on Agricultural Engineering (Vol. 6). 2-6 February, Morocco.

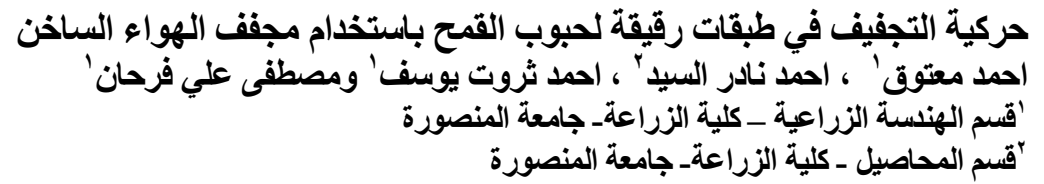

تم اجر اء البحث لدر اسة تأثير كل من درجة حرارة هو اء التجفيف ورطوبتة النسبية على خصائص التجفيف لحبوب القمح واختبار ومقارنة ثلاث نماذج رياضية مختلفة

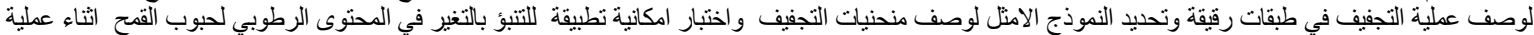

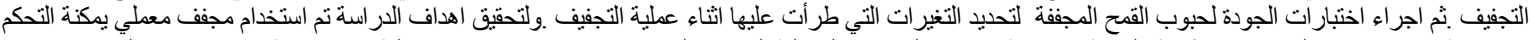

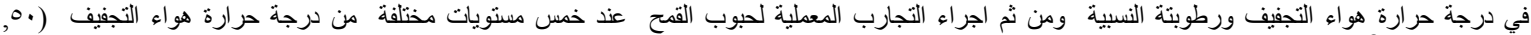

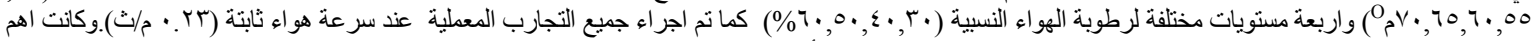

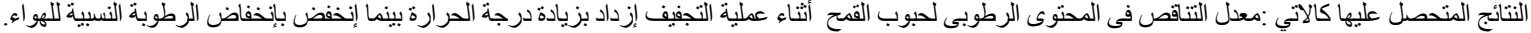

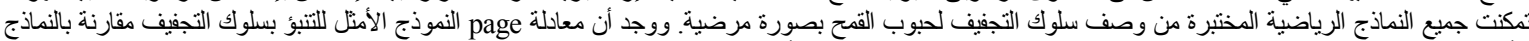

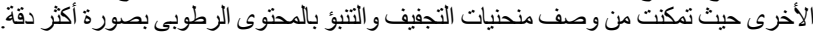

